\title{
Accountability of a Notary in Court for Underhand Deed Legalized by a Notary
}

\begin{abstract}
Agung Aditya
Faculty of Law, Universitas Pekalongan, Pekalongan, Indonesia

\begin{tabular}{l}
\hline Info Artikel \\
\hline Keywords: \\
Legal protection; Traditional \\
Knowledge; Copyrights. \\
\\
P-ISSN: 1412-6605 \\
E-ISSN: 2301-6426 \\
Kata kunci: \\
Notaris; Legalisasi; \\
Tanggungjawab; Pengadilan. \\
agung.manding30@gmail.com \\
\hline
\end{tabular}

Abstract

This research aims to provide an explanation of the responsibility of notary public in the Court of deed under the hands of a notary public, facts in the field show that a Notary is often called to the court to give testimony on the evidence of the trial, namely a letter under the hand legalized by the notary, therefore there needs to be an explanation of the notary's liability for the deed made or legalized. Notary responsibility for deed under legalized hands is heavier than waarmerking, because the parties sign before notary public where notary does not ascertain the content of a deed whether it is wrong or true. Although only legalization but the deed under the hand has the value of being a valid and strong evidence in court so that sometimes dragging a notary witness in the trial. Notary can be subject to criminal sanctions if they are proven to have harmed one of the parties and the Notary can also be subject to civil sanctions in the form of compensation according to what was suffered by the parties.

\begin{tabular}{l} 
Abstrak \\
\hline Penelitian ini mempunyai tujuan untuk memberikan penjelasan \\
mengenai tanggung jawab Notaris di Pengadilan atas akta dibawah \\
tangan yang dilegalisasi oleh Notaris, Fakta dilapangan menunjukkan \\
bahwa seorang Notaris sering dipanggil ke pengadilan untuk \\
memberikan kesaksian atas bukti persidangan yaitu surat dibawah \\
tangan yang dilegalisasi oleh notaris tersebut, oleh sebab itu perlu \\
adanya penjelasan mengenai pertanggungjawaban Notaris atas akta \\
yang dibuat maupun di legalisasi. Tanggungjawab notaris terhadap \\
akta dibawah tangan yang telah dilegalisasi lebih berat daripada \\
waarmerking, karena para pihak tanda tangan di hadapan Notaris \\
dimana Notaris tidak memastikan isi mengenai suatu akta apakah salah \\
atau benar. Meskipun hanya legalisasi tetapi akta dibawah tangan \\
tersebut mempunyai nilai menjadi alat bukti yang sah dan kuat di \\
pengadilan sehingga kadang menyeret notaris dijadikan saksi dalam \\
persidangan. Notaris dapat dikenakan sanksi Pidana apabila dengan \\
terbukti merugikan salah satu pihak dan juga Notaris dapat dikenakan \\
sanksi Perdata berupa ganti kerugian sesuai yang diderita oleh para \\
pihak.
\end{tabular}
\end{abstract}

\section{Introduction}

Indonesia as a legal state based on Pancasila and the 1945 Constitution of the Republic of Indonesia, the Unitary State of the Republic of Indonesia must carry out law enforcement that reflects justice, certainty, and maximum benefit for the 
purpose of protecting the law, order, and the welfare of the people. In order to support the success of law enforcement, authentic tools are needed regarding legal conditions, events, or actions carried out through certain positions, one of which is a notary as a public official. ${ }^{1}$

The development of socio-cultural and economic life in society makes every society need a person (figure) whose information is reliable, trustworthy, whose signature and seal (stamp) provide strong guarantees and evidence, an impartial expert, and an advisor who has no defects (onkreukbaar or unimpeachable), who kept his mouth shut and made a pact that could protect him in the days to come. If an advocate defends someone's rights when a problem arises, then a notary must try to prevent the difficulty from occurring. ${ }^{2}$

In Article 1 of Law Number 2 of 2014 concerning Amendments to Law Number 30 of 2004 concerning the Position of a Notary, it is stated that notary is a public official who is authorized to make an authentic deed and has other authorities as referred to in this Law or based on other Laws." Notaries can be said to be public officials because they are given and equipped with general authority or power concerning the public (openbaar gezag). ${ }^{3}$ In carrying out his position in a neutral position between the parties who will ask for his services, to ensure impartiality, the Notary must have integrity, be independent and impartial, and not be influenced by the wishes of certain parties, especially if the desire violates the applicable legal provisions or harm the other party.

There are 3 conditions that must be met in an authentic deed, namely made by or before public officials in power (authorized public officials) where the matter issued by the authorized official in question must be trusted and recognized as being in accordance with the law (rechtmatig), for example, a deed made by a Notary, auction official, the official making civil registration deeds, and so on, the formal or form of the deed has been determined by law, and the deed is at the place where the public official is authorized or at the legal domicile of the public official.

These three conditions must be met cumulatively if one of these conditions is not met, the power of proof of the deed is not authentic and only has the power of proof as an underhand deed. Including the legalized underhand deed as regulated in Article 15 paragraph (2), namely ratifying the underhanded letter and setting the date of the underhanded letter. The Notary's responsibility is limited to the authenticity of the signatures of the parties and the certainty of the date of the legalized deed, before signing the parties, the Notary explains the

${ }^{1}$ Sang Ayu Made Ary Kusuma Wardhani, 'Tanggung Jawab Notaris Terhadap Legalisasi Akta Dibawah Tangan', Kerta Dyatmika, 17.2 (2020).

${ }^{2}$ Tan Thong Kie, Studi Notariat \& Serba-Serbi Praktek Notaris (Jakarta: Ichtiar Baru Van Hoeve, 2011).

${ }^{3}$ R. Sugondo Notodisoerjo, Hukum Notariat Di Indonesia Suatu Penjelasan (Jakarta: Raja Grafindo Persada, 1983). 
contents of the deed which is explained by the Notary (Voorhouden) to the parties. ${ }^{4}$.

In practice, people often ask that the agreement/deed under the hand be "ratified" by a notary. Legalized in this case the Notary is obliged to be responsible for what is legalized/legalized. There are so many Notaries who are dragged into court because the legalized deed has problems, either data falsification or the agreement under the hand is detrimental to the parties even though the notary only ratifies it. The summons of a Notary in court due to a legalized deed are actually not justified by law because the contents of the deed are not the responsibility of the Notary concerned.

\section{Methods}

This legal research uses a type of legal research that is juridical normative, namely where the law is conceptualized as what is written in statutory regulations (law books) or the law is conceptualized as a rule or norm which is a benchmark for human behavior that is considered appropriate. According to Soerdjono and Sri, normative juridical research is a legal research method that is carried out by examining library materials or secondary materials. ${ }^{5}$

\section{Results and Discussion}

There are 2 (two) types of Notary deed, namely the deed made by the Notary (door) in Notary practice called the Relaas Deed or Minutes Deed which contains a description of the Notary which is seen and witnessed by the Notary himself at the request of the parties so that the actions or actions of the parties what is done is stated in the form of a Notary Deed; Deed made before (tenoverstaan) a Notary, in practice a Notary is called a Deed of Parties, which contains a description or statement, statements of the parties given or told before a Notary. The parties wish that their description or statement be put in the form of a Notary Deed. ${ }^{6}$

An underhand deed before being legalized by a notary is called an underhand agreement. An underhand agreement is an agreement that is intentionally made by the parties for proof without the assistance of an authorized public official. ${ }^{7}$ Private deeds have their characteristics and characteristics, including: ${ }^{8}$ Freeform, It does not have to be made before a public official, still has the power of proof as long as it is not denied by the maker, meaning that the contents of the deed do not need to be proven again unless someone can prove otherwise (deny the

\footnotetext{
${ }^{4}$ Kie.

${ }^{5}$ Soerjono Soekanto, Pengantar Penelitian Hukum (Jakarta: UI-Press, 2011).

${ }^{6}$ G.H.S. Lumban Tobing, Peraturan Jabatan Notaris (Jakarta: Erlangga, 1992).

7 Victor M. Situmorang and Cormentyna Sitanggang, Gross Akta Dalam Pembuktian Dan Eksekusi (Jakarta: Rineka Cipta, 2005).

8 Iga Bgs Agastya Pradnyana, 'Tanggung Jawab Notaris Atas Kebenaran Akta Di Bawah Tangan Yang Dilegalisasi' (Universitas Udayana, 2017).
} 
contents), and If it must be proven, the evidence must also be accompanied by witnesses and other evidence. Therefore, usually in a private deed, it is better to include two adult witnesses to strengthen the evidence.

Regarding legalization in Article 1874 of the Civil Code, it is explained that underhand writings are considered to be signed underhand deeds, letters, registers, household affairs letters, and other writings made without the intermediary of an employee. general. By signing writing under the hand which is equivalent to a thumbprint, affixed with a dated statement from a Notary or another official appointed by law from which it turns out that he knows the person who put the thumbprint, or that this person was introduced to him, that the contents are the deed has been explained to that person, and that after that the thumbprint is affixed in front of a public employee. This employee must record the writing. By virtue of this law, further regulations regarding the said statement and bookkeeping may be enacted. ${ }^{9}$

Legalization is regulated in Article 15 paragraph (2) of Law Number 30 of 2004 concerning the Position of a Notary that in legalizing a handwritten deed, the Notary only matches the signature and determines the certainty of the date the deed is brought in hand. Legalizing means making it legal, such as ratifying (letters, deeds, and so on), this is reinforced in Article 56 of Law Number 30 of 2004 concerning the Position of a Notary which explains that an underhand letter that is legalized or legalized must be given a stamp and notary's initial and signature. Based on statutory regulations, several types of legalization practices are known. ${ }^{10}$

First, the legalization of digital data. Second, the legalization of the deed under the hand, and third, the legalization of the signature. From this description, it can be said that legalization has various meanings and methods, namely: (1) ratifying by stating that it is true regarding the compatibility of the digital data substance with the physical; (2) To ratify by stating that it is true that the subject signed on the deed is the person or official whose name is written on the deed; (3) To ratify by stating correctly regarding the signer, content, and date in the deed under the hand; (4) Validate by stating that the data contained therein is correct after being checked with the redister at the issuing institution and (5) validated by stating that the photocopy is correct and matches the original. Often people make agreements, written by the parties, not made before a notary. Such writing is called an underhand deed or in Dutch it is called (onderhands). ${ }^{11}$

\footnotetext{
${ }^{9}$ Moh. Iqra Syabani Korompot, Sholahuddin Al-Fatih, and David Pradhan, 'The Principle of Equality Before the Law in Indonesian Corruption Case: Is It Relevant?', Journal of Human Rights, Culture and Legal System, 1.3 (2021).

${ }^{10}$ Ratna Sofiana, Satria Utama, and Abdur Rohim, 'The Problems of Halal Certification Regarding Consumer Protection in Malaysia and Indonesia', Journal of Human Rights, Culture and Legal System, 1.3 (2021).

${ }^{11}$ Kohar A., Hukum Kenotariatan (Bandung: Alumni, 2004).
} 
The objectives of the legalization of the signing of the deed under the hand are: Regarding the authority to legalize and waarmerking, Ordonantie Staatblad 1916 Number 46 in conjunction with Number 43 states that:

a. Article 1: "In addition to the Notary, also appointed to legalize and warmer the deed under the hand is the Regent, the Head of the District Court and the Mayor."

b. Article 2 paragraph (2): "A private deed which is not legalized if it is to be used as evidence in court, it can be waarmerking by a Notary by affixing the words "marked" and signed by a Notary and mentioning the days and months during waarmerking."

c. Article 3 of the Staatblad 1916 number 46 mentions a regulation concerning the register that must be made to record the private deeds, among others stipulating that the books in the register contain ${ }^{12}$

Notaries are often called in courts because there are 2 factors, the first being suspected of participating in crimes in legalizing private deeds or being used as witnesses in trials related to deeds legalized by the notary. ${ }^{13}$ If the private deed contains real truth, then the legalization of the private deed by a notary will not cause legal problems in the future. However, if the private deed contains untruths that are not known by the Notary, then the legalization of the underhanded deed containing the untruth does not ensnare the Notary who legalizes it. ${ }^{14}$

On the other hand, if the Notary knows the untruths contained in the private deed, but in order to get big profits, the Notary conspires with the court so that the Notary concerned is willing to legalize the private deed containing the untruth. In this condition, the legalizing Notary is also involved in legal problems that arise later which leads to criminal/civil sanctions, warnings, or revocation of practice licenses and dishonorably dismissed as regulated in Article 12 of Law Number 30 of 2004 concerning Notary Positions. ${ }^{15}$

If a witness is used as a witness regarding an underhand deed legalized by a Notary, the Notary also cannot come directly to fulfill the summons because he must obtain permission from the MPD (Regional Supervisory Council), because the MPD is the one who supervises the Notary and in addition to supervising the MPD is also authorized to take a photocopy of the minutes of the deed. and letters attached to the minutes of the deed or the Notary's protocol in the case of a

\footnotetext{
${ }^{12}$ Notodisoerjo.

${ }^{13}$ Resti Dian Luthviati and Suviwat Jenvitchuwong, 'Implementation of Halal Product Assurance in the Pharmaceutical Sector in Indonesia', Journal of Human Rights, Culture and Legal System, 1.3 (2021).

${ }^{14}$ Utkarsh K. Mishra and Abhishek Negi, 'Should Trade Remedies Be Eliminated from WTO: A Response to Tania Voon', Journal of Human Rights, Culture and Legal System, 1.3 (2021).

${ }^{15}$ Saidah Fasihah Binti Che Yussoff and Rohaida Nordin, 'Freedom of Expression in Malaysia: Compatibility with the International Human Rights Standard', Bestuur, 9.1 (2021), 34-42.
} 
Notary deviation and summoning the Notary to attend the examination related to the deed he made or the Notary protocol that is in the Notary deviation. ${ }^{16}$ The MPD (Regional Supervisory Council) itself has no right to impose sanctions on Notaries who violate the code of ethics or do not comply with the Law on Notary Positions, only MPW (Regional Supervisory Council) has the right to impose sanctions. ${ }^{17}$

The responsibilities of a notary follow the principle of responsibility based on fault (based on the fault of liability). In making an authentic deed, the Notary must be responsible if there is an error or violation on the deed made by the appearing party, so as long as the Notary carries out his authority according to the regulations, the Notary concerned cannot be held accountable. In this case, the Notary only records what was submitted by the parties to be written into the deed, false information submitted by the parties is the responsibility of the parties. ${ }^{18}$

The above shows that in accordance with Article 1874a of the Civil Code and the description in the chapter above, basically, a Notary who legalizes an underhand deed does not have responsibility for the contents of the deed made before him, because the contents of the deed are the will of the parties. and is an agreement desired by the parties themselves. The responsibility of the Notary is only to provide legal certainty regarding the identity, date, and signature of the parties, meaning that there is the certainty of legal consequences under the hand which states that the parties are present and know the contents of the deed which has been read by the Notary previously. Whereas in carrying out the legalization, the Notary does not take sides with either party and must be neutral. ${ }^{19}$

\section{IV.Conclusion}

Based on the conclusions of the research and analysis in this article, we can conclude that, first, the responsibility of a notary towards his profession as a public official making an authentic deed includes legal actions carried out by a notary including the making of an authentic deed during the act committed by a notary does not violate the laws and regulations, whether criminal, civil or the notary code of ethics. Thus, the Notary is only responsible for the standard form of the authentic deed determined in the form of law. Second, the responsibility of a Notary to an underhand agreement containing elements of unlawfulness and

${ }^{16}$ Siti Rahma Novikasari, Duc Quang Ly, and Kerry Gershaneck, 'Taxing Micro, Small and Medium Enterprises in Yogyakarta: Regulation and Compliance', Bestuur, 9.1 (2021), 43-52.

17 Wardhani.

18 Utkarsh K. Mishra and Abhishek Negi, 'Transgender and the Right to Employment in India: Analysing the Trajectories of Discrimination', Bestuur, 9.1 (2021), 26-33.

${ }^{19}$ Loresta Cahyaning Lintang, Adriano Martufi, and J.W. Ouwerker, 'The Alternative Concepts of Blasphemy Law in Indonesia: Legal Comparison with Ireland and Canada', Bestuur, 9.1 (2021), $13-25$. 
which has been legalized by a Notary, so it does not have responsibility for the contents of the deed made before him because both the parties and the contents of the deed are the wishes and agreements desired by the parties. The Notary is not responsible for this. The responsibility of a Notary is only limited to providing legal certainty only includes the date, the identity of the parties, as well as the signatures of the parties on the agreement because, in the legalization process, the Notary has read out the contents of the agreement that has been agreed upon by the parties. Notaries can get sanctions if it can be proven otherwise.

\section{Refrences}

A., Kohar, Hukum Kenotariatan (Bandung: Alumni, 2004)

Harahap, M.Yahya, Hukum Acara Perdata Tentang Gugatan, Persidangan, Penyitaan, Pembuktian Dan Putusan Pengadilan (Jakarta: Sinar Grafika, 2013)

Jamil, M, 'Pemalsuan Akta Autentik Sebagai Aspek Pidana Notaris', Jurnal Bestuur, 7.2 (2019)

Kie, Tan Thong, Studi Notariat \& Serba-Serbi Praktek Notaris (Jakarta: Ichtiar Baru Van Hoeve, 2011)

Korompot, Moh. Iqra Syabani, Sholahuddin Al-Fatih, and David Pradhan, 'The Principle of Equality Before the Law in Indonesian Corruption Case: Is It Relevant?', Journal of Human Rights, Culture and Legal System, 1.3 (2021)

Lintang, Loresta Cahyaning, Adriano Martufi, and J.W. Ouwerker, 'The Alternative Concepts of Blasphemy Law in Indonesia: Legal Comparison with Ireland and Canada', Bestuur, 9.1 (2021), 13-25

Luthviati, Resti Dian, and Suviwat Jenvitchuwong, 'Implementation of Halal Product Assurance in the Pharmaceutical Sector in Indonesia', Journal of Human Rights, Culture and Legal System, 1.3 (2021)

Mishra, Utkarsh K., and Abhishek Negi, 'Should Trade Remedies Be Eliminated from WTO: A Response to Tania Voon', Journal of Human Rights, Culture and Legal System, 1.3 (2021)

- - - 'Transgender and the Right to Employment in India: Analysing the Trajectories of Discrimination', Bestuur, 9.1 (2021), 26-33

Notodisoerjo, R. Sugondo, Hukum Notariat Di Indonesia Suatu Penjelasan (Jakarta: Raja Grafindo Persada, 1983)

Novikasari, Siti Rahma, Duc Quang Ly, and Kerry Gershaneck, 'Taxing Micro, Small and Medium Enterprises in Yogyakarta: Regulation and Compliance', Bestuur, 9.1 (2021), 43-52

Pradnyana, Iga Bgs Agastya, 'Tanggung Jawab Notaris Atas Kebenaran Akta Di Bawah Tangan Yang Dilegalisasi' (Universitas Udayana, 2017)

Situmorang, Victor M., and Cormentyna Sitanggang, Gross Akta Dalam Pembuktian Dan Eksekusi (Jakarta: Rineka Cipta, 2005) 
Soekanto, Soerjono, Pengantar Penelitian Hukum (Jakarta: UI-Press, 2011)

Sofiana, Ratna, Satria Utama, and Abdur Rohim, 'The Problems of Halal Certification Regarding Consumer Protection in Malaysia and Indonesia', Journal of Human Rights, Culture and Legal System, 1.3 (2021)

Tobing, G.H.S. Lumban, Peraturan Jabatan Notaris (Jakarta: Erlangga, 1992)

Wardhani, Sang Ayu Made Ary Kusuma, 'Tanggung Jawab Notaris Terhadap Legalisasi Akta Dibawah Tangan', Kerta Dyatmika, 17.2 (2020)

Yussoff, Saidah Fasihah Binti Che, and Rohaida Nordin, 'Freedom of Expression in Malaysia: Compatibility with the International Human Rights Standard', Bestuur, 9.1 (2021), 34-42 